\title{
Дмитро Прочухан
}

викладач циклової комісії комп’ютерних та інформаційних дисциплін, Харківський комп'ютерно-технологічний коледж Національного технічного Університету «Харківський політехнічний інституг»; Харків, Україна

E-mail:dprochuhan@gmail.com

\section{УМОВИ САМОСТІЙНОЇ РОБОТИ МАЙБУТНІХ ТЕХНІКІВ-ПРОГРАМІСТІВ ПІД ЧАС ВИКОРИСТАННЯ ІНТЕРАКТИВНИХ ЕЛЕМЕНТІВ ДИСТАНЦІЙНОГО КУРСУ}

Анотація: У статті розглянуто практичний досвід впроваджсення $і$ застосування технології дистаниійного навчання для студентів Харківського комп'ютерно-технологічного коледжу Національного технічного Університету «Харківський політехнічний інститут». $B$ проиесі проведеного дослідження описано умови самостійної роботи майбутніх техніків-програмістів під час використання інтерактивних елементів середовища Moоdle на прикладі дисципліни «Розробка клієнт-серверних застосувань». Запропоновано рачіональні засоби, форми та методи навчання, які реалізуються за допомогою електронного навчального курсу. Визначено переваги дистанційного навчання, які сприяють підвищенню якості знань, розвитку фахових компетенцій молодиих спеиіалістів .

Ключові слова: дистанщійне навчання, самостійна робота, електронний курс, інтерактивний елемент, форум, чат, блог.

\section{Dmytro Prochukhan}

An extended abstract of a paper on subject of:

«The conditions of independent work of future technicians-programmers during the use of interactive elements of the controlled from distance course»

Problem setting. For institutions of higher education of the I-II level of accreditation, the introduction of distance learning to improve the training of specialists is an extremely important problem. The introduction of a distance course for the training of future technicians-programmers is particularly relevant. In the educational process of higher education institutions, considerable attention should be paid to the independent work of students, so that the future specialist entered the labour market with a well-formed need to update their knowledge in professional activities.

Recent research and publications analysis. Analysis of recent research and publications testifies to the significant attention of foreign and domestic scientists to the problem of introduction of remote technologies in the educational process of educational institutions. A significant contribution to the development of distance learning was made by the American scientist M. Mur, who revealed the theoretical and practical aspects of the application of distance learning. A. Kej, $\mathrm{H}$. Rambl, K. Harri, F. Da Kosta, A, Pelisari, I.Honsales explored the problems of using distance learning in higher education. $N$. Tuncay addressed the issue of the application of innovation in distance education. The experience of foreign scientists was used in their works by domestic scientists.

(C) Дмитро Прочухан, 2019 
M.Vyshnevs'ka considered the application of the experience of distance education in higher educational institutions of Ukraine. The state and prospects of development of distance learning is covered in the works by M. Karpenko, I.Liashenko, S. Sysoieva, K.Osadcha. Questions of application of distance learning technologies in higher education are investigated in the works of A. Zabolots'kyj, Yu. Ivanov, O. Ol'khovs'ka, D. Ol'khovs'kyj. L.Ohnichuk, H. Lohvinenko, O.Naumuk considered issues of organization of independent work of students using distance learning technologies.

Paper objective. The purpose of the article is to substantiate the impact of the use of electronic distance learning elements to improve the conditions of independent work of future technicians-programmers, as well as identify the advantages and disadvantages of the use of distance learning of future technicians-programmers.

Paper main body. Independent study is one of the leading activities of students in the educational process. In independent study it is necessary to implement a comprehensive model of advanced education, to develop such characteristics as independence, professionalism, mobility, sociability. The most effective in the organization of independent study of students is a systematic, integrated approach. In the modernization of education the most important role is distance learning, which is one of the most effective means of self-organization. Distance learning differs from traditional forms by the following characteristics: flexibility, modularity, large audience coverage, efficiency, adaptability, a new role of the teacher. One of the distance learning systems is Moodle, which provides communication of participants of the educational process, implemented in the form of conferences, forums, chats. Kharkiv computer and technology College (KCTC), that is the part of the NTU "KPI", introduced the system of online courses. Mixed learning, which involves the preservation of the General principles of the traditional educational process using distance learning using the Moodle system, was used for the development of tasks of independent work for training of technicians-programmers of specialty 112 "Computer science and information technology" on the subject "Development of client-server applications". The distance learning course facilitates the work of both the teacher and the student. Kharkiv computer and technology College (KCTC), that is the part of the NTU "KPI", introduced the system of online courses. Mixed learning was used for the development of tasks of independent work for training of technicians-programmers of specialty 112 "Computer science and information technology" on the subject "Development of client-server applications". The distance learning course facilitated the work of both the teacher and the student. For the organization of interactive interaction between the student and the teacher there are such elements of Moodle as a forum and chat, which are effective means of implementing the concept of "subject-subject". The forum provides opportunities for asynchronous interaction between the teacher and the student.

All types of forums were used in Moodle. A simple single discussion was applied to elaborate complex topics of independent work. It was possible to increase the number of issues discussed from the features of object-oriented programming, web servers, frameworks. The type of forum "everyone publishes one discussion" was used to speed up the implementation of practical work. The question-and-answer forum was used to consider the use of built-in functions for working with strings, files, directories and their further use in the programming process.

As a result, the number of programs has increased, these functions were used as well. The forum in the format of a blog contributed to the improvement of creativity, increasing the number of developed presentations. The standard forum for General use provided an improvement in the rate of successfully completed projects when students worked in mini-groups. The forums provided full support for asynchronous independent work of the teacher and students. A chat was used by the author for group and individual 
consultations to maintain the synchronous interaction of the participants of the educational process. The combination of forum and chat provided the necessary level of interaction to master the issues of independent work. Quality control of independent work of students is carried out by means of testing. There was an increase in absolute academic performance in comparison with the same indicators in 2018. The survey showed a high level of positive perception of the e-course.

Conclusions of the research. The use of forums has brought such results: compared with 2018, it was possible to

Постановка проблеми в загальному вигляді та ii зв'язок із важливими науковими чи практичними завданнями.

Бурхливий розвиток сучасних інформаційних технологій обумовлює модернізацію освітніх систем i пошук інноваційних технологій навчання. В Україні суть модернізації означено в Концепції розвитку дистанційної освіти [9]. Для досягнення зазначених результатів необхідно розвивати дистанційну освіту, запровадження якої в Україні передбачено Національною програмою інформатизації [6]. Згідно 3 указом Президента України від 25 червня 2013 р. про національну стратегію розвитку, дистанційна освіта повинна стати важливим чинником професійного зростання населення [23].

Для закладів вищої освіти I-II рівня акредитації важливою є проблема застосування дистанційного навчання для покращення якості підготовки фахівців. Особливо актуальним $є$ питання впровадження дистанційного курсу для підготовки майбутніх техніківпрограмістів. Компанії, що займаються розробкою програмного забезпечення, цінують працівників, які постійно прагнуть професійно зростати, безперервно займатися самоосвітою i consider 6 additional issues on complex topics of independent work, the number of errors in programs decreased by $14 \%$, the number of successful projects increased by 2. In the process of using the chat, students developed the skills of self-formulation and defending their own point of view, there was an activation of passive students due to the tactful reminder of the teacher to contact him with requests for help. The qualitative progress of students increased by $31 \%$. Prospects for further research are to study the conditions and opportunities for effective use in the distance learning course webinar as an innovative learning technology.

саморозвитком. Фахівець, що не прагне крокувати в ногу 3 новітніми інформаційними технологіями, стає не конкурентоздатним на ринку праці. Брак самостійності, самоорганізованості, нездатності до самоосвіти не дозволяє повноцінно працювати за своєю спеціальністю. Тому у навчальному процесі закладу вищої освіти слід приділити увагу самостійній роботі студентів, щоб майбутній фахівець увійшов на ринок праці 3 міцно сформованою потребою оновлювати свої знання у професійній діяльності.

Аналіз останніх досліджень i публікацій, у яких започатковано розв'язання цісї проблеми $i$ на які спирається автор. Встановлено наявність значного інтересу іноземних $\mathrm{i}$ вітчизняних науковців до проблеми впровадження дистанційних технологій у навчальний процес закладів освіти. Теоретичні основи дистанційної освіти заклали зарубіжні вчені Д. Кормье, Д. Сіменс і С. Даунс. Значний внесок для розвитку дистанційного навчання зробив американський науковець М. Мур, який розкрив теоретичні та практичні аспекти його застосування [30].

В роботі [25, с. $1-20]$ розглянуто розвиток інформаційно-комунікативних засобів навчання в світі. В статті [28] 
розкриті можливості дистанційного навчання як засобу підвищення освітніх можливостей населення країн, що розвиваються. А. Кей [29], Г. Рамбл, К. Гаррі [31], Ф. Да Коста, А, Пелісарі, I. Гонсалес [26, с. 117-135] досліджували проблеми використання дистанційного навчання у вищій освіті. Н. Тункай розглядав питання застосування інновацій у дистанційній освіті [32, с. 20-30]. Г. Ебі досліджував засоби підготовки експертів із дистанційного навчання [27]. Перспективи розвитку дистанційної освіти в зарубіжних країнах також розглядали Д. Андерсон, С. Віллер, Т. Едвард, Р. Клінг, Дж.О'Роурке, Д. Парриш, Р. Філіпс, Н. Хара, Д. Мюллер, Д. Кіган, А. Кларк, М. Томпсон.

$$
\text { Досвід іноземних вчених }
$$

використали в своїх працях вітчизняні науковці. М. Вишневська розглянула питання застосування досвіду дистанційної освіти США у вищих навчальних закладах України [3, с. 92-94]. Я. Соколовський, О. Сторожук, I. Крошний розглядали сучасні тенденції інформаційно-комунікаційних технологій (IKT) в освіті $[22$, с. $243-248]$. У статті Ю. Опанасюка [16, с. 49-53] визначено основні напрями віртуальної освіти в Україні. Стан та перспективи розвитку дистанційного навчання висвітлено у роботі М. Карпенко, I. Ляшенко, С. Сисоєвої, К. Осадчої [21, с. 2-5]. Питання застосування технологій дистанційного навчання у вищій освіті розглянуто у дослідженнях А. Заболоцького [5, с.19-23.], Ю. Іванова, О. Ольховської, Д. Ольховського [7, с. 5862]. Особливості впровадження дистанційної освіти в Україні досліджували наступні вчені: В. Биков, Н. Морзе, М. Мазур, Н. Сиротенко, П. Стефаненко, В. Кухаренко, С. Пахолко, В. Семенець, Н. Мась, В. Тришин, А. Толбатов.

Покращення самостійної роботи засобами дистанційного навчання обгрунтовано у роботах таких вчених, як C. Архангельський, С. Гончаренко, М. Махмутова, Є. Полот, В. Сагарда, Л. Виготський, П. Гальперін, Г. Костюк,
О. Матюшкін, Н. Тализіна. Л. Огнічук [15, с. 187-195], Г. Логвіненко [12, с.348355], О. Наумук [14, c. 242-245] розглядали питання організації самостійної роботи студентів 3 використанням технологій дистанційного навчання. Формування компетентностей викладача-тьютора досліджувалось О. Коневщинською [10, с.20-32].

\section{Виділення не вирішених раніше} частин загальної проблеми, котрим присвячусться дана стаття. В розглянутих публікаціях досліджується досвід підготовки майбутніх фахівців вищих навчальних закладів 3-4 рівня акредитації та для загально-освітніх установ. Питання використання інтерактивних елементів дистанційного професійного навчання для самостійної роботи студентів у підготовці майбутніх техніків-програмістів I-II рівня акредитації залишаються недостатньо дослідженими.

Формулювання цілей статті. Мета статті полягає в обгрунтуванні впливу використання елементів електронного дистанційного курсу, спрямованого на покращення умов самостійної роботи, а також виявленні переваг і недоліків у використанні форми дистанційного навчання для майбутніх техніків-програмістів.

Виклад основного матеріалу 3 повним обгрунтуванням отриманих результатів. Процес глобалізації, постійний розвиток сучасних інноваційних та інформаційних технологій, потреби суспільства в мобільності обумовлюють пошук новітніх шляхів навчання. В модернізації освіти найсуттєвішу роль займає дистанційне навчання, яке $\epsilon$ одним 3 найбільш ефективних засобів організації самостійної діяльності [4, с. 251-254].

Аналіз наукових статей, педагогічної та методичної літератури свідчить про те, що існує достатньо 
багато тлумачень змісту дефініції "самостійна робота". Р. Нізамов, Н. Сагіна в своїх працях розглядають цю дефініцію як різноманітні види індивідуальної та групової пізнавальної діяльності студентів у аудиторний та позаудиторний час. В. Граф, І. Ільясов, В. Ляудіс, Н. Сагіна, О. Чиж тлумачать самостійну роботу як навчальну діяльність студентів, яка відбувається за відсутності викладача i без його безпосередньої допомоги. С. Архангельський, Л. Деркач, I. Шайдур, Н. Сагіна в своїх працях наголошували на урахуванні індивідуальних особливостей i пізнавальних можливостей студентів. В контексті підготовки майбутніх техніківпрограмістів, ми вважаємо, що під час самостійної роботи треба реалізовувати комплексну модель випереджувальної освіти, розвивати якості, які на даний час затребувані на ринку праці самостійність, професіоналізм, мобільність, комунікабельність. Самостійну роботу слід розглядати як складне педагогічне явище, яке включає систему поєднаних структурних і функціональних компонентів, що утворюють цілісну єдність, підпорядковану цілям виховання, освіти i розвитку в умовах опосередкованого управління нею i самоуправління [11, с.79-84].

Автор вважає, що найбільш ефективним в організації самостійної роботи студентів $\epsilon$ планомірний, інтегрований підхід відповідно до освітньо-професійної програми підготовки майбутнього фахівця. Завдання викладача - керувати процесом самостійної пізнавальної діяльності, стимулювати студентів таким чином, щоб він став максимально ефективним. Викладачу потрібно, по-перше, перейти від суб'єкт-об'єктних відносин зі студентом до суб' єкт-суб' єктних, щоб подолати можливі психологічні бар'єри. По-друге, йому слід займатися розробкою нового змісту, принципів, методів, форм і засобів реалізації процесу організації самостійної роботи студентів.

Для успішної реалізації цих завдань слід створити засоби й інструменти, які б дозволили успішно подолати проблему самостійної роботи студентів. У цих умовах першочергового значення набуває проблема технізації самостійної роботи засобами дистанційного навчання. Дистанційне навчання представляє собою нову організацію освіти, що грунтується на використанні як кращих традиційних методів отримання знань, так і нових інформаційних та телекомунікаційних технологій, a також на принципах самоосвіти. Воно призначене для широких верств населення незалежно від матеріального забезпечення, місця проживання та стану здоров'я. Дистанційне навчання дає змогу впроваджувати інтерактивні технології викладання матеріалу, здобувати повноцінну вищу освіту або підвищувати кваліфікацію і має наступні переваги: гнучкість, актуальність, зручність, модульність, економічна ефективність, інтерактивність, відсутність географічних кордонів для здобуття освіти [1].

Актуальність дистанційного навчання проявляється у можливості впровадження новітніх педагогічних, психологічних і методологічних розробок із розбиттям матеріалу на окремі функціонально завершені модулі (теми), які вивчаються поступово, залежно від засвоєння і відповідають здібностям окремого студента або групи загалом. Для того, щоб дистанційне навчання було максимально ефективним, його потрібно правильно організувати за допомогою системи організаційних, технічних, програмних та методичних заходів [2, с. 21-27].

Навчальний процес можна реалізувати як в умовах географічної віддаленості студента та викладача, так i безпосередньо в закладі освіти для 
формування самостійної діяльності студента щодо засвоєння програми навчальної дисципліни.

Дистанційне навчання від традиційних форм відрізняють такі характерні риси:

- гнучкість: студенти мають можливість займатися в зручний для себе час, у зручному місці, самостійно обирати темп роботи;

- модульність: вони мають можливість із набору незалежних навчальних курсів (модулів) формувати навчальний план, що відповідає індивідуальним чи груповим потребам;

- охоплення великої аудиторії: одночасне звернення до багатьох джерел навчальної інформації (електронних бібліотек, баз даних, баз знань тощо), спілкування за допомогою телекомунікаційного зв'язку студентів між собою та з викладачами;

- економічність: ефективне використання навчальних площ та технічних засобів, концентроване та уніфіковане надання інформації, використання та розвиток комп'ютерного моделювання сприяють зниженню витрат на підготовку фахівців;

- технологічність: використання в навчальному процесі новітніх досягнень інформаційних технологій, які сприяють входженню людини у світовий інформаційний простір;

- нова роль викладача: педагог координує пізнавальний процес, постійно вдосконалює навчальні курси, підвищує творчу активність i кваліфікацію відповідно до нововведень та інновацій.

Однією 3 систем дистанційного навчання є Moodle [18]. Moodle (Modular Object-Oriented Dynamic Learning Environment) - це модульне об'єктноорієнтоване динамічне навчальне середовище, яке надає викладачам, студентам та адміністраторам розвинутий набір інструментів для комп'ютеризованого навчання та виконання завдань самостійної роботи. Ця система призначена для організації навчання онлайн у мережевому середовищі, забезпечує різноманіття процедур, комбінування яких сприяє самостійному навчанню в освітньому закладі. Середовище Moodle надає навчальному закладу такі можливості: реалізація модульної організації навчального процесу за вимогами Болонської декларації, формування повнокомплектного науковометодичного забезпечення дисциплін, організація навчально-методичного процесу, створення Internet-середовища для електронних форм навчання, забезпечення оперативного контролю навчального процесу.

Дистанційне середовище надає засоби доступу до ресурсів та управління ними, забезпечує комунікаційну взаємодію учасників освітнього процесу, що реалізовується у формі конференцій, форумів, чатів.

Використання мережевих технологій дозволяє студенту будувати свою стратегію самостійної роботи та сприяє не тільки засвоєнню студентами знань, умінь, навичок, форм професійної поведінки, а й формуванню певної структури особистісних якостей. Подання знань в Moodle як динамічної, мультимодальної структури, у формуванні якої беруть участь студенти, сприяе набуттю студентами досвіду самостійного поповнення та оновлення професійних знань, особистісної причетності до цього процесу та відповідальності за нього [24, с.79-89].

Сучасні підходи до самостійної роботи студентів як до провідної, а у найближчому майбутньому й основної форми навчання в умовах інформаційного суспільства вимагають від викладачів розробки дистанційного курсу 3 
елементами інтерактивного навчання. інформаційні технології» 3 дисципліни Завдяки тому, що система Moodle «Розробка клієнт-серверних застосувань» підтримує інтерфейс понад 80 мов застосовується змішане навчання, яке (включаючи локалізацію системи передбачає збереження загальних українською мовою), вона була успішно принципів побудови традиційного впроваджена і використовується в 60 тися- навчального процесу разом 3 чах організацій у понад 200 країн світу [18]. використанням дистанційного навчання

В НТУ «ХПІ» також було успішно за допомогою системи Moodle для впроваджено систему дистанційних опанування технологією виконання курсів [20]. Перед ЗВО I-II рівня завдань самостійної роботи. У навчальних акредитації, як і перед ЗВО III-IV рівня, $\epsilon$ планах обсяг самостійної роботи повинен актуальним питання впровадження становити не менше $1 / 3 \mathrm{i}$ не більше 2/3 дистанційної освіти для полегшення загального обсягу навчального часу роботи викладача та студента i студента, відведеного на вивчення покращення якості викладання конкретної дисципліни. В таблиці 1 навчальних дисциплін. В Харківському наведено розподіл годин аудиторної i комп'ютерно-технологічному коледжі самостійної роботи дисциплін (ХКТК), що входить до структури НТУ професійного спрямування спеціальності «ХПІ», також було впроваджено систему 112 «Комп’ютерні науки та інформаційні дистанційних курсів [19]. Для підготовки технології», що викладаються автором в техніків-програмістів у ХКТК НТУ «ХПІ» спеціальності 112 «Комп’ютерні науки та

\section{Таблиця 1 - Розподіл годин аудиторної і самостійної роботи дисциплін професійного спрямування}

\begin{tabular}{|c|c|c|c|c|c|}
\hline Назва дисципліни & $\begin{array}{l}\mathrm{K} \\
\mathrm{y} \\
\mathrm{p} \\
\mathrm{c}\end{array}$ & $\begin{array}{l}\text { Загальний } \\
\text { обсяг, год }\end{array}$ & $\begin{array}{l}\text { Аудиторна } \\
\text { робота, год }\end{array}$ & $\begin{array}{l}\text { Самостійна } \\
\text { робота, год }\end{array}$ & $\begin{array}{c}\text { Співвідношення } \\
\text { самостійної } \\
\text { роботи до } \\
\text { загального } \\
\text { обсягу,\% }\end{array}$ \\
\hline Теорія алгоритмів & 2 & 108 & 63 & 45 & 42 \\
\hline Навчальна практика-1 & 3 & 156 & 60 & 96 & 62 \\
\hline $\begin{array}{l}\text { Розробка клієнт- } \\
\text { серверних застосувань }\end{array}$ & 4 & 162 & 84 & 78 & 48 \\
\hline
\end{tabular}

Загальна кількість годин дисципліни «Розробка клієнт-серверних застосувань» (табл. 1) становить 162 години, 3 яких 84 години складають аудиторні заняття (64 години - лекції, семінари, комбіновані заняття), а 78 годин відведено на самостійну роботу, що становить $48 \%$ від загальної кількості часу.

Велика кількість матеріалу для самостійного опрацювання утворює для студента перепони в його опрацюванні. Дистанційний курс дозволяє полегшити роботу як викладача, так і студента. За рахунок гнучкості системи Moodle студенти мають можливість займатися в зручний для себе час, у зручному місці, обирати темп самостійної роботи. Позитивним впливом дистанційного навчання на студента $\epsilon$ підвищення його творчого та інтелектуального потенціалу шляхом самоорганізації з використанням інформаційно-комунікаційних технологій. Якщо розглянути особливості дистанційного навчання 3 точки зору використання його під час самостійної роботи та комунікації між викладачем i 
студентом, то можна визначити такі його

характерні риси: самоосвіта як основа дистанційного навчання, що передбачає мотивацію студента щодо власного навчання, а також певний рівень самоорганізації особистості; спілкування викладача та студента за принципом «один до одного», що відповідає за формою та змістом індивідуальній консультації; спілкування «одного до багатьох», що за змістом нагадує роботу викладача з групою студентів.

Для організації інтерактивної взаємодії між студентом і викладачем призначені елементи Moodle форум і чат, які $\epsilon$ ефективними засобами реалізації концепції «суб'єкт-суб'єктних» відносин.

У ХКТК НТУ «ХПІ» було проведено дослідження щодо використання засобів дистанційного навчання у двох навчальних групах з дисципліни «Розробка клієнт-серверних застосувань». Студенти групи ОПК - 415 навчалися в 2019 році 3 використанням середовища Moodle, а група ОПК - 414 навчалася в 2018 році за класичною програмою без елементів ДН. В процесі навчання група ОПК - 415 активно використовувала форуми і чат. Форуми надали широкі можливості асинхронної взаємодії викладача i студентів. В середовищі Moodle було використано всі доступні типи форумів: проста одиночна дискусія, кожен студент публікує одну дискусію, форум «питання-відповідь», форум у форматі блогу, стандартний форум для загального використання.

$$
\text { Проста одиночна дискусія }
$$

складається 3 однієї теми i використовувалася для того, щоб провести обговорення з певного питання. В дистанційному курсі цей вид форуму застосовувався автором разом зі студентами групи ОПК-415 у процесі опрацювання складних тем самостійної роботи - таких як особливості використання об'єктно-орієнтованого програмування (ООП) у мові РНР
(Personal Home Page) для розробки клієнт-серверних додатків, використання фреймворків, застосування веб-серверів.

Студенти отримували на свою електронну пошту повідомлення, коли на форумі з'являлася нова інформація. Автор долучав усіх студентів до обговорення питань самостійної роботи, використовуючи опцію «підписати всіх». Нові повідомлення автоматично розсилалися учасникам форуму за допомогою електронної пошти. За рахунок використання опції «оцінка» кожне повідомлення студентів отримало певний бал. Якщо студент вдало опановував підняту на форумі тему, то він мав можливість відписатися від розсилки.

$$
\text { Аналіз опрацьованих тем }
$$

самостійної роботи показав наступні результати. У 2018 році у групі ОПК-414 без залучення засобів дистанційного навчання було розглянуто 3 питання ООП (інкапсуляція, наслідування i поліморфізм) . У 2019 з групою ОПК-415 вдалося збільшити кількість розглянутих питань ООП до п'яти: додатково було опановано використання трейтів та обробку виключень. В 2018 році були опрацьовані питання використання фреймворків Laravel i Symfony, застосування веб-сервера Nginx. За рахунок використання засобів дистанційного навчання в 2019 році, окрім Nginx було розглянуто особливості роботи 3 веб-серверами Internet Information Services и Cherokee, додаткові фреймворки CodeIgniter, Zend. Цей тип форуму застосовувався автором також для того, щоб зробити оголошення щодо консультацій, змін в розкладі графіку навчального процесу. Для цього створювалася примусова підписка, за умови якої всі учасники дистанційного курсу отримують на свою електрону пошту повідомлення.

Тип форуму «кожен публікує одну дискусію», що надає можливість певному студенту розпочати тільки одну дискусію 
3 можливістю відповіді інших учасників форуму. Він використовувався, коли студент виконував практичне завдання самостійної роботи і стикався 3 певними труднощами. Студенти додавали файл до повідомлення, щоб демонструвати фрагменти непрацюючого програмного коду, зображення помилок, отримання кваліфікованої допомоги від викладача або інших студентів. Якщо учасник форуму змінював своє повідомлення й додавав новий файл (наприклад, нову версію програмного коду), то попередній файл замінювався. Якщо повідомлення редагувалося, а поле із прикріпленим файлом залишалося порожнім, то попередня версія файлу використовувалася разом 3 повідомленням. Застосування цього типу форуму залучало інших студентів до розв'язання вищого класу завдань, сприяло прискоренню вирішення завдань практичного спрямування. У 2018 році кількість самостійних робіт, які студенти виконували у визначені терміни, становила 63\%. У 2019 році цей показник досяг $75 \%$. За рахунок щоденних консультацій покращилася якість програмного коду. В програмуванні зменшилася кількість помилок щодо використання синтаксису на $13 \%$, а в алгоритмах програм - на 15\%. Форум формату «питання-відповідь» було застосовано для стимулювання студентів до інтерактивного процесу обговорення питань, адже учасники бачать відповіді інших учасників форуму тільки після того, як розмістять свою відповідь. В межах цього форуму студенти розглядали особливості використання вбудованих функцій роботи 3 рядками, файлами, каталогами, які дозволяють оптимізувати програмний код. Результатом роботи цього форуму стало те, що студенти частіше використовували їх в подальших розробках. Якщо в 2018 році функції роботи $з$ рядками, файлами, каталогами було використано у 7 програмах, то у 2019 році таких програм стало 11.

Форум у форматі блогу - дуже зручний інструмент для того, щоб кожний студент міг поділитися власним досвідом створення клієнт-серверного застосування. Такий тип форуму було впроваджено для творчої самореалізації студентів, висвітлювання результатів власної пізнавальної діяльності, демонстрації презентацій. Учасники форуму ділилися із іншими своїми розробками i напрацюваннями. Студентами було створено 52 презентації, кращі з яких було розміщено в основному контенті дистанційного курсу. У порівнянні 3 минулим роком кількість презентацій збільшилась на 18. Стандартний форум для загального використання було створено для ефективної роботи при застосуванні проектного навчання. Під час аудиторної роботи студенти були об'єднані в команди для створення клієнт-серверного застосування мережевої взаємодії, а вже під час створення програмного продукту використовували форум для обговорення проблемних питань. На форумі було утворено відповідні групи, в межах яких студенти набували досвіду роботи в команді. Результатами стало успішне виконання таких проектів: система перевірки якості знань 3 програмування, поштова служба, диспетчер розсилки, інформаційні сайти з математики, фізики, інформатики. В 2019 році було успішно виконано 7 проектів, а в минулому - 5. Також форум став майданчиком для обговорення питань доцільності використання певного програмного забезпечення. Для запобігання спаму, дублювання контенту, надмірного навантаження для цього типу форуму були зроблені наступні обмеження: кількість доданих студентом файлів не повинна перевищувати 9, а кількість повідомлень обмежується числом 20. Досвід використання різних типів форуму систематизовано у таблиці 2.

Створені форуми забезпечили повноцінну підтримку асинхронної самостійної роботи викладача і студентів. 


\begin{tabular}{lcc} 
ОРГАНІЗАЦІЙНО-ПЕДАГОГІЧНІ $\quad$ УМОВИ & ФОРМУВАННЯ & ПРОФЕСІЙНӦ̈ \\
МАЙСТЕРНОСТІ МАЙБУТНІХ СПЕЦІАЛІСТІВ & \\
\hline
\end{tabular}

Таблиця 2 - Використання різних типів форумів у дистанційному курсі

\begin{tabular}{|c|c|c|}
\hline Тип форуму & $\begin{array}{c}\text { Способи використання в } \\
\text { дистанційному курсі }\end{array}$ & Результат \\
\hline Проста одиночна дискусія & $\begin{array}{c}\text { Оголошення, опрацювання питань } \\
\text { підвищеного рівня складності під } \\
\text { керівництвом викладача }\end{array}$ & $\begin{array}{c}\text { Збільшення кількості } \\
\text { розглянутих тем самостійної } \\
\text { роботи }\end{array}$ \\
\hline $\begin{array}{c}\text { Кожен публікує одну } \\
\text { дискусію }\end{array}$ & $\begin{array}{c}\text { Допомога у виконанні індивідуальних } \\
\text { завдань }\end{array}$ & $\begin{array}{c}\text { Зменшення кількості } \\
\text { помилок, покращення якості } \\
\text { програмного коду }\end{array}$ \\
\hline Питання-відповідь & $\begin{array}{c}\text { Інтерактивне опрацювання питань } \\
\text { студентів }\end{array}$ & Оптимізація програмного коду \\
\hline Форум у форматі блогу & $\begin{array}{c}\text { Самореалізація студента, } \\
\text { стимулювання пізнавальної діяльності }\end{array}$ & $\begin{array}{c}\text { Збільшення кількості творчих } \\
\text { робіт } \\
\end{array}$ \\
\hline $\begin{array}{c}\text { Стандартний форум для } \\
\text { загального використання }\end{array}$ & $\begin{array}{c}\text { Проектний метод розробки } \\
\text { обговорення загальних питань } \\
\text { використання програмного } \\
\text { забезпечення }\end{array}$ & $\begin{array}{c}\text { Збільшення кількості успішно } \\
\text { виконаних проектів }\end{array}$ \\
\hline
\end{tabular}

Для підтримки синхронної взаємодії учасників навчального процесу було застосовано інтерактивний елемент чат. Чат завантажується тільки в поточний момент часу i являє собою вікно, в якому йде потік повідомлень від його учасників. Під час чат-сесії студент заходив до системи під своїм логіном і надсилав повідомлення, яке одразу з'являлося в загальному потоці. Чат існує, тільки якщо в ньому в певний момент часу зустрілися хоча б дві людини. Але при цьому існує можливість за допомогою налаштувань зберігати історію повідомлень в архіві. Чат був використаний автором для проведення групових та індивідуальних консультацій студентів у форматі «питання-відповідь». Під час індивідуальних консультацій за побажаннями певних студентів був організований приватний чат, коли повідомлення міг бачити тільки викладач і студент, якому надавалася консультація. Студент мав можливість повідомити викладачу про те, що всі його питання вичерпані за допомогою використання опції «показувати діяльність як виконану». За допомогою чату студенти домовлялися про спільне обговорення і у зручний для себе час організовували дискусію з питань розробки проектів.

Поєднання форуму i чату забезпечило необхідний рівень взаємодії для опанування питань щодо самостійної роботи.

Контроль якості самостійної роботи студентів здійснено за допомогою тестування. Окрім використання таких традиційних видів тестів як питання 3 вибором однієї правильної відповіді, множинного вибору, встановлення відповідності, було використано тести виду есе, що дозволяють студентові надіслати викладачу відповіді з декількох речень. Есе було впроваджено як інструмент звітності щодо виконання завдань самостійної роботи. Показники за результатами тестування засвідчили високий ступінь засвоєння знань під час самостійної роботи.

Після завершення курсу навчання було проведено аналіз рівня успішності студентів (табл.3). Використано наступні формули для обчислення показників абсолютної та якісної успішності:

Загальна успішність $=($ кількість "5" + кількість "4" + " кількість " 3") × 100\% / загальна кількість студентів.

Якість знань = (кількість "5" + кількість "4") × 100\% / загальна кількість студентів.

За допомогою цих формул зроблено порівняльний аналіз рівня навчальних досягнення двох груп.

Дослідна група ОПК - 415:

Загальна успішність $=(7+8+7) \times 100 \% / 24$ $=92 \%$ 
$24=63 \%$

Якісна успішність $=(7+8) \times 100 \% /$

Дослідна група ОПК - 414:
Загальна успішність $=(3+4+12) \times$

$100 \% / 22=86 \%$

Якісна успішність $=(3+4) \times 100 \% /$

Таблиця 3 - Показники успішності навчальних груп дисципліни «Розробка кліснт-серверних застосувань»

\begin{tabular}{|c|c|c|c|c|c|c|c|c|}
\hline \multirow[t]{2}{*}{$\begin{array}{c}\text { Роки } \\
\text { навчання }\end{array}$} & \multirow{2}{*}{ Група } & \multirow{2}{*}{ 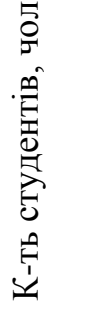 } & \multicolumn{4}{|c|}{ Кількість, шт. } & \multirow{2}{*}{ 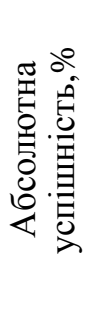 } & \multirow{2}{*}{ 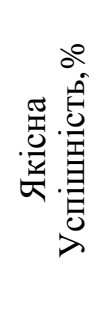 } \\
\hline & & & $« 5 »$ & «4» & $\ll 3 »$ & «2» & & \\
\hline $2017-2018$ & ОПК-414 & 22 & 3 & 4 & 12 & 3 & 86 & 32 \\
\hline 2018-2019 & ОПК-415 & 24 & 7 & 8 & 7 & 2 & 92 & 63 \\
\hline
\end{tabular}

Таким чином, зафіксовано збільшення абсолютної успішності на $6 \%$ і якісної успішності на $31 \%$ у 2019 році у порівнянні з аналогічним показниками 2018 року.

Анкетування, проведене серед студентів після опанування електронного курсу, показало, що 95\% студентів позитивно оцінили інноваційні засоби навчання. Студенти вказали такі переваги дистанційного навчання: логічна послідовність викладання матеріалу, проста навігація, зручність читання, наявність зворотного зв'язку, чатів, форумів для безпосереднього вирішення проблемних ситуацій разом 3 викладачем, швидка перевірка практичних робіт викладачем.

Висновки 3 даного дослідження та перспективи подалыших розвідок у даному напрямку. Таким чином, виконане дослідження дозволяє зробити наступні висновки про покращення умов

\section{Список літератури:}

1. Балан, Л. О. (2016) Формування у майбутніх інженерів-програмістів готовності до використання освітніх дистанційних технологій у професійній діяльності [Текст]: Автореф. дис. ... канд. пед. наук : спец. 13.00.04 - теорія та методика професійної освіти. Одеса. ДЗ "Південноукр. нац. пед. ун-т ім. К. Д. Ушинського". $20 \mathrm{c}$.

2. Васильєв, А. \& Шкарлет, С. самостійної роботи майбутніх техніківпрограмістів.

Застосування форумів принесло такі результати: у порівнянні з 2018 роком вдалося розглянути 6 додаткових питань зі складних тем самостійної роботи, зменшилася кількість помилок у програмах на $14 \%$, кількість виконаних успішних проектів збільшилася на 2. В процесі використання чату у студентів розвинулися навички самостійного формулювання і відстоювання власної точку зору, відбулася активізація пасивних студентів за рахунок тактовного нагадування викладача про звернення до нього з проханнями про допомогу. Якісна успішність студентів зросла на $31 \%$.

Перспективи подальших розвідок полягають у дослідженні умов i можливостей ефективного використання в дистанційному курсі вебінару як інноваційної технології навчання.

(2014) Інноваційні аспекти IT-підготовки та підвищення кваліфікації фахівців: досвід українських університетів. Вища освіта України. №. 2. С. 21 - 27.

3. Вишневська, М. О. (2018) Напрями упровадження досвіду дистанційної освіти США у вищих навчальних закладах України Scientific Letters of Academic Society of Michal Baludansky. Vol. 6, No. 6. P. 92-94.

4. Дивак, В. (2013) Особливості 
самостійної роботи студентів вищих навчальних закладів в умовах заочної форми навчання. Інформаційні технологіі i засоби навчання. № 1. С.251 - 254 .

5. Заболоцький, А.Ю. (2016) Сучасний стан дистанційного навчання у ВНЗ України. Вісник Дніпропетровського університету імені Альфреда Нобеля Серія «Педагогіка $і$ психологія». Педагогічні науки. № 2 (12). С. $19-23$.

6. Закон про Національну програму інформатизації. [Електронний ресурс] Режим доступу: http://zakon.rada.gov.ua/laws/show/74/98\% D0\%B2\%D1\%80

7. Іванов, Ю., Ольховська, О. \& Ольховський, Д. (2017) Особливості розвитку дистанційних технологій у ВНЗ Укоопспілки "Полтавський університет економіки i торгівлі». Вісник Національного університету «Львівська політехніка». Серія: Інформатизація вищого навчального закладу. №879. C. $58-62$.

8. Карпенко, М. М. (2014) Розвиток дистанційного навчання як відповідь на сучасні виклики для України. Фахове видання з економічних, філософських, політичних наук та державного управління. Затверджено постановами Президії ВАК України. С. 102.

9. Концепція розвитку дистанційної освіти в Україні. [Електронний ресурс] Режим доступу: http://www.osvita.org.ua/ distance/pravo/00.html.

10. Коневщинська, О.Е. (2014) Формування IКТ-компетентності викладачів-тьюторів ресурсних центрів дистанційної освіти. Інформаційні технології $i$ засоби навчання. Том 42, №4. C. $20-32$

11.Круглик, В. С. (2016) Дистанційні технології навчання як засіб професійної підготовки майбутніх інженерів-програмістів. Молодь $і$ ринок. T. 6. №. 137 .C. $79-84$.

12. Логвіненко, В.Г (2015) Самостійна робота студентів у середовищі дистанційного навчання Moodle. Современные инновационные технологии подготовки инженерных кадров для горной промышленности и транспорта. C. 348-355
13. Ляшенко, I. В. (2015) Перспективи розвитку дистанційного навчання у вищій школі. Народна освіта.. №1(25). [Електронний ресурс] Режим доступу: https://www.narodnaosvita. kiev.ua/?page_id=2682

14. Наумук О. В. Організація самостійної роботи інженерівпрограмістів засобами дистанційних технологій із дисципліни Адміністрування комп'ютерних мереж. Науковий вісник Мелітопольського державного педагогічного університету. Серія: Педагогіка. 2013. №. 2. С. 242-245.

15. Огнівчук, Л. (2014) Організація самостійної роботи студентів ВН3 із застосуванням технологій E-learning. Інформаційні технології $i$ засоби навчання. № 41 (3), С. 187-195.

16. Опанасюк, Ю. (2016) Дистанційне навчання як наслідок еволюції традиційної системи освіти. Вищуа освіта України.. № 1. С. 49-53. [Електронний ресурс] Режим доступу: http://nbuv.gov.ua/UJRN/vou_2016_1_10

17. Осадчий, В. В. \& Осадча, К. П. (2015) Сучасні реалії і тенденції розвитку інформаційно-комунікаційних технологій в освіті. Інформаційні технологї̈ $i$ засоби навчання. № 48 (4). С. 47-57.

18. Офіційний сайт Moodle. [Електронний ресурс] Режим доступу: https://moodle.org/

19. Сайт дистанційного навчання ХКТК НТУ «ХПІ». [Електронний ресурс] Режим доступу: http://ctcollege.net/moodle/

20. Сайт Центру дистанційного навчання НТУ «ХПІ». [Електронний ресурс]. Режим доступу: http://dl.khpi.edu.ua/

21. Сисоєва, С.О \& Осадча, К.П. (2019) Стан технології та перспективи дистанційного навчання в Україні. //Інформаційні технологї $i$ засоби навчання,. Том 70. №2. С.2-5.

22. Соколовський, Я. І., Сторожук, О. Л. \& Крошний I. М. (2015) Застосування сучасних інформаційнокомунікаційних технологій для організації дистанційного навчання. Науковий вісник НЛТУ України. Вип. 25.6. С. 243 - 248.

23. Указ Президента України про 
Національну стратегію розвитку освіти в Україні на період до 2021 року [Електронний ресурс] Режим доступу: http://zakon4.rada.gov.ua/laws/show/344/2013

24. Щербина, О. А. (2015) Швидке створення облікових записів студентів та їх реєстрація в курсах платформи Moodle. Інформаційні технологї в освіті: Збірник наукових праць. №23. С. $79-89$.

25. Adams, B., Cummins, M., Davis, A., Freeman, A., Hall, C. \& Ananthanarayanan, V. (2017) «NMC Horizon Report: 2017». Higher Education Edition. Austin, Texas: The New Media Consortium. P. $1-20$.

26. Da Costa, F. \& Pelissari, A. (2018) Gonzalez, I. Corporate Image of Public Higher Education Institutions: Relevant Factors to Distance Learning Students. Turkish Online Journal of Distance Education, vol. 19 (1). P. $117-135$.

27. Eby, G. (2015) Identification, Evaluation, and Perceptions of Distance

\section{References:}

1. Balan, L. O. (2016) Formuvannia u majbutnikh inzheneriv-prohramistiv hotovnosti do vykorystannia osvitnikh dystantsijnykh tekhnolohij $u$ profesijnij diial'nosti [Formation of future programmers engineers preparedness to use educational distance technologies in their professional activities]: avtoref. dys. kand. ped. nauk: spets. 13.00.04 - teoriia ta metodyka profesijnoi osvity. Odesa. DZ "Pivdennoukr. nats. ped. un-t im. K. D. Ushyns'koho". 20 p. [in Ukrainian]

2. Vasyl'iev, A. \& Shkarlet, S. (2014) Innovatsijni aspekty IT-pidhotovky ta pidvyschennia kvalifikatsii fakhivtsiv [Innovative aspects of IT training and professional development: experience of Ukrainian universities]: dosvid ukrains'kykh universytetiv. Vyscha osvita Ukrainy. №. 2. P. 21 - 27. [in Ukrainian]

3. Vyshnevs'ka, M. O. (2018) Napriamy uprovadzhennia dosvidu
Education Experts. IGI Global. 354 p.

28. Frey, M., Pokkiyarath, M., Mohan, R., Shibu, N., Gracia, V. \& Mohan, V. (2017) Elevating education of India's rural village girls through distance learning technology supported by sustainable electricity. Global Humanitarian Technology Conference (GHTC). [Електронний ресурс] Режим доступу: https://doi.org/10.1109/ GHTC.2017.8239300

29. Kaye, A. \& Rumble, G. (2018) Distance Teaching For Higher and Adult Education. London, UK: Routledge. 380 p.

30. Moore, M. (2013) Handbook of distance education. Edition 3. Routledge.752 p.

31. Rumble, G. \& Harry, K. (2018) The Distance Teaching Universities. London, UK: Routledge. 258 p.

32.Tuncay, N. (2016) Smartphones as tools for Distance Education. Journal of Educational and Instructional Studies in the World. P. $20-30$.

dystantsijnoi osvity SShA u vyschykh navchal'nykh zakladakh Ukrainy [Areas of introduction of the experience of distance education of the USA in higher educational institutions of Ukraine]. Scientific Letters of Academic Society of Michal Baludansky. Vol. 6, No. 6. P. 92-94. [in Ukrainian]

4. Dyvak, V. (2013) Osoblyvosti samostijnoi roboty studentiv vyschykh navchal'nykh zakladiv $v$ umovakh zaochnoi formy navchannia. [Peculiarities of independent work of students of higher educational establishments in the conditions of correspondence form of studying]. Informatsijni tekhnolohii i zasoby navchannia. № $\quad 1 . \quad$ P.251 $\quad$ - 254 . [in Ukrainian]

5. Zabolots'kyj, A.Yu. (2016) Suchasnyj stan dystantsijnoho navchannia $u$ VNZ Ukrainy. [The current state of distance learning in higher educational institutions of Ukraine]. Visnyk Dnipropetrovs'koho universytetu imeni Al'freda Nobelia Seriia «Pedahohika i psykholohiia». Pedahohichni 
nauky. № 2 (12). P. 19 - 23. [in Ukrainian]

6. Zakon pro Natsional'nu prohramu informatyzatsii. [Law on the National Program of Informatization]. Access mode: http://zakon.rada.gov.ua/laws/show/74/98\% D0\%B2\%D1\%80[in Ukrainian]

7. Ivanov, Yu., Ol'khovs'ka, O. \& Ol'khovs'kyj, D. (2017) Osoblyvosti rozvytku dystantsijnykh tekhnolohij u VNZ Ukoopspilky "Poltavs'kyj universytet ekonomiky $i$ torhivli». [Features of the development of remote technologies in the universities of Ukoopspilks "Poltava University of Economics and Trade"]. Visnyk Natsional'noho universytetu «L'vivs'ka politekhnika». Seriia: Informatyzatsiia vyschoho navchal'noho zakladu. №879. P.58 - 62. [in Ukrainian]

8. Karpenko, M. M. (2014) Rozvytok dystantsijnoho navchannia iak vidpovid' na suchasni vyklyky dlia Ukrainy. Fakhove vydannia $z$ ekonomichnykh, filosofs'kykh, politychnykh nauk ta derzhavnoho upravlinnia. [Development of distance learning as a response to current challenges for Ukraine]. Zatverdzheno postanovamy Prezydii VAK Ukrainy. P. 102. [in Ukrainian]

9. Kontseptsiia rozvytku dystantsijnoi osvity v Ukraini. [Concept of development of distance education in Ukraine]. Access mode: http://www.osvita.org.ua/distance/pravo/00.h tml. [in Ukrainian]

10. Konevschyns'ka, O.E. (2014) Formuvannia IKT-kompetentnosti vykladachiv-t'iutoriv resursnykh tsentriv dystantsijnoi osvity. [Formation of ICT competence of faculty-tutors of resource centers of distance education]. Informatsijni tekhnolohii i zasoby navchannia. Tom 42, №4. P. 20 - 32[in Ukrainian]

11.Kruhlyk, V. S. (2016) Dystantsijni tekhnolohii navchannia iak zasib profesijnoi pidhotovky majbutnikh inzhenerivprohramistiv. [Distance learning technologies as a means of training future engineer programmers]. Molod' i rynok. T. 6. №. 137.P. 79 - 84. [in Ukrainian]

12. Lohvinenko, V.H (2015) Samostijna robota studentiv u seredovyschi dystantsijnoho navchannia Moodle. Sovremennye ynnovatsyonnye tekhnolohyy podhotovky ynzhenernykh kadrov dlia hornoj promyshlennosty y transporta. [ndependent work of students in the Moodle distance learning environment]. P. 348-355 [in Ukrainian]

13. Liashenko, I. V. (2015) Perspektyvy rozvytku dystantsijnoho navchannia $u$ vyschij shkoli. [Prospects for the development of distance learning in higher education]. Narodna osvita. №1 (25). Access mode: https://www.narodnaosvita.kiev.ua/?page_id=2682 [in Ukrainian]

14. Naumuk O. V. (2013) Orhanizatsiia samostijnoi roboty inzhenerivprohramistiv zasobamy dystantsijnykh tekhnolohij iz dystsypliny Administruvannia komp'iuternykh merezh. [Organization of independent work of program engineers by means of remote technologies in discipline. Administration of computer networks]. Naukovyj visnyk Melitopol's'koho derzhavnoho pedahohichnoho universytetu. Seriia: Pedahohika. №. 2. P. 242-245. [in Ukrainian]

15. Ohnivchuk, L. (2014) Orhanizatsiia samostijnoi roboty studentiv VNZ iz zastosuvanniam tekhnolohij Elearning. [Organization of independent work of students of higher educational institutions using E-learning technologies]. Informatsijni tekhnolohii i zasoby navchannia. № 41 (3), P. 187-195. [in Ukrainian]

16. Opanasiuk, Yu. (2016) Dystantsijne navchannia iak naslidok evoliutsii tradytsijnoi systemy osvity. [Distance learning as a consequence of the evolution of the traditional system of education]. Vyscha osvita Ukrainy. № 1. S. 49-53. Access mode: http://nbuv.gov.ua/UJRN/vou_2016_1_10 [in Ukrainian] 
17. Osadchyj, V. V. \& Osadcha, K. P. (2015) Suchasni realii i tendentsii rozvytku informatsijno-komunikatsijnykh tekhnolohij $v$ osviti. [Modern realities and trends of the development of information and communication technologies in education]. Informatsijni tekhnolohii i zasoby navchannia. № 48 (4). $\quad$ P. 47-57. [in Ukrainian]

18. Ofitsijnyj sajt Moodle. [Moodle Official Site]. Access mode: https://moodle.org/

19. Sajt dystantsijnoho navchannia $K h K T K N T U$ «KhPI». [The site of distance learning of KCTK NTU "KhPI"]. Access mode: http://ct-college.net/moodle/ [in Ukrainian]

20. Sajt Tsentru dystantsijnoho navchannia NTU «KhPI». [The site of the Center for Distance Learning NTU "KhPI"]. Access mode: http://dl.khpi.edu.ua/ [in Ukrainian]

21. Sysoieva, S.O \& Osadcha, K.P. (2019) Stan tekhnolohii ta perspektyvy dystantsijnoho navchannia v Ukraini. [The state of technology and the prospects of distance learning in Ukraine]. Informatsijni tekhnolohii i zasoby navchannia,. Tom $70 . \quad$ №2. P.2-5. [in Ukrainian]

22. Sokolovs'kyj, Ya. I., Storozhuk, O. L. \& Kroshnyj I. M. (2015) Zastosuvannia suchasnykh informatsijnokomunikatsijnykh tekhnolohij dlia orhanizatsii dystantsijnoho navchannia. [Application of modern information and communication technologies for the organization of distance learning]. Naukovyj visnyk NLTU Ukrainy. Vyp. 25.6. P. $243-$ 248. [in Ukrainian]

23. Ukaz Prezydenta Ukrainy pro Natsional'nu stratehiiu rozvytku osvity $v$ Ukraini na period do 2021 roku. [Decree of the President of Ukraine on the National Strategy for the Development of Education in Ukraine for the period up to 2021]. Access mode: http://zakon4.rada.gov.ua/ laws/show/344/2013[in Ukrainian]
24. Scherbyna, O. A. (2015) Shvydke stvorennia oblikovykh zapysiv studentiv ta ikh reiestratsiia $v$ kursakh platformy Moodle. [Quickly create student accounts and sign up for Moodle courses]. Informatsijni tekhnolohii $\mathrm{v}$ osviti: Zbirnyk naukovykh prats'. №23. P. 79 - 89. [in Ukrainian]

25. Adams, B., Cummins, M., Davis, A., Freeman, A., Hall, C. \& Ananthanarayanan, V. (2017) «NMC Horizon Report: 2017». Higher Education Edition. Austin, Texas: The New Media Consortium. P. 1 - 20. [in Ukrainian]

26. Da Costa, F. \& Pelissari, A. (2018) Gonzalez, I. Corporate Image of Public Higher Education Institutions: Relevant Factors to Distance Learning Students. Turkish Online Journal of Distance Education, vol. 19 (1). P. 117 - 135.

27. Eby, G. (2015) Identification, Evaluation, and Perceptions of Distance Education Experts. IGI Global. 354 p.

28. Frey, M., Pokkiyarath, M., Mohan, R., Shibu, N., Gracia, V. \& Mohan, V. (2017) Elevating education of India's rural village girls through distance learning technology supported by sustainable electricity. Global Humanitarian Technology Conference (GHTC). [Електронний ресурс] Режим доступу: https://doi.org/10.1109/ GHTC.2017.8239300

29. Kaye, A. \& Rumble, G. (2018) Distance Teaching For Higher and Adult Education. London, UK: Routledge. 380 p.

30. Moore, M. (2013) Handbook of distance education. Edition 3. Routledge. $752 \mathrm{p}$.

31. Rumble, G. \& Harry, K. (2018) The Distance Teaching Universities. London, UK: Routledge. 258 p.

32.Tuncay, N. (2016) Smartphones as tools for Distance Education. Journal of Educational and Instructional Studies in the World. P. $20-30$. 